ISSN 1112-9867

http://www.jfas.info

\title{
HYDRO- CHEMICAL STUDY OF AGRICULTURAL WATER RESOURCES IN THE GHAEMSHAR PLAIN (NORTHEAST OF IRAN)
}

\author{
H. Moghimi
}

Department of Geology, University of Payam-e Noor, PO Box 19395-4697, Tehran, IRAN

Published online: 05 June 2016

\begin{abstract}
Analysis of water samples involves measuring density of main cations and anions and parameters Iranian National Standard was used for analyzing. Samples were collected from 22 areas and different physico-chemical parameters such as $\mathrm{pH}$, EC, TDS and major anion, cations and some parameters such as SAR, PI, KI and etc, were assayed by chemical relations, to evaluate the quality of groundwater and its property for irrigation. Due to the Gibbs diagram, samples which are formed, affecting by geological formations, Caspian Sea salt water intrusion and connate water aquifers, are in areas of rock-water, evaporation and crystallization reactions. Therefore groundwater quality will decrease for using in agriculture and the other consumptions and also infiltration of them will not be useful. Area of study is suitable and allowed, according to different methods of the water sources surveying.
\end{abstract}

Keywords: Ghaemshar plain; Kelly’s index; Permeability index; SAR.

Author Correspondence, e-mail: homayounmoghimi@pnu.ac.ir doi: http://dx.doi.org/10.4314/jfas.8vi2s.24

\section{INTRODUCTION}

Groundwater is one of the vital and essential sources around the world. Approximately, almost a third of world people use the groundwater for drinking waters. Consequently, in 
most regions of world, the amount of discharged water is over than feed rate by irregular using of these sources cause the problem of water shortage. There are a lot of variables related to quality of water which is dependent to the time and location frequencies. A most important challenging issue is the understanding these fluctuations and recognizing the reasons of them which can be natural changings or human activities. Being conscious about the environmental conditions and comparing them with the reference conditions and inexpensive and comfort measuring them represent an ideal variable. Chemical combination of groundwater is affected by some factors which are; The combination of spatial and temporal distribution of rainfall, climatic conditions and catchment, geology and tectonics, Aquifer conditions, the topography of the study area and etc. collection of these factors causes the variety of different waters which are different locational and timely [1]. The early twentieth century, rapid growth of population increases the need for fresh water. After groundwater was accounted as a renewable resources and a component of ecosystem, threats of these sources affect the human activities directly [2]. Since the main activities of hydrology are to provide the drinking, industrial and agricultural waters, quality, proportion and protection of groundwater is the most important problem [3]. Qualified data about the groundwater is the very well help for Lithology or geologic history of the study area and shows the feeding, discharge and reserves states of groundwater. The quality of groundwater for drinking and irrigation is dependent to type and level of soluble salts. These materials are based on the dissolution or weathering of rocks and soil which can be based on the solution of some sediment such as Carbonates, Sulfates, Chlorides and the other minerals [4]. The quality of groundwater is affected by physical and chemical factors which are related to geological formations and human activities. Chemistry of groundwater depends on the amount of atmosphere inputs, types of weathering and the sources of natural and artificial contaminants such as saltwater intrusion (sea and fossil aquifers), Domestic, industrial and agricultural wastewaters, addition to the lithology of rocks and water retention time in contact with rock forming [5]. Excessive farming activities, indiscriminate harvesting and too much irrigation in the studying area are the most important causes in pollution of groundwater. Hydrogeological, physico-chemical and hydrogeochemical data were combined to analysis the chemical controlling mechanisms of 
groundwater and affecting factors in the studying area of Ghaemshahr plain. In this study, the affecting made and interactions of the geological components with the groundwater by hydrogeochemical approaches were surveyed in different diagrams. Researchers and organizations studied the area of study, excessively.

\subsection{Precedence studies}

The Researches Water Resources Organization [6], the project of integration of Mazandaran Rivers basin studies for providing the drinking and irrigation water, that the project of prohibition extension of consumption water providing region to protect the quality and quantity of drinking water resources and prevent the harmful effects of exploiting. In order to supply drinking water of Tehran metropolis (about $258 \mathrm{MCM}$ per year), studies in terms of quantitative and qualitative in catchment area of Babol and Haraz have been conducted [7]. Mahabghods consulting engineers [8], accurate semi - formal Agrology studies of Talar Babol - Haraz River lands for recognition of types of soils and to diagnose soil types and determine the susceptibility of the land and correctly using of the water and soil sources. Modeling of groundwater flow and geochemical investigation of drinking and irrigation water wells in Sari plain [9], Shows that change the quality of irrigation water for agriculture depends on geology, saltwater intrusion and harvesting is irregular. Another investigation has done in case of qualitative and quantitative characteristics of Sari aquifer which effective factors on low quality of ground water, penetration of different wastewater, brackish water, seawater mixture and evaporation of groundwater has been detected [10]. Gharemohammadlu [11], hydrogeochemical studies is in confirmation the saltwater penetration in the wells of Sari (Ghaemshar) plain. Due to irregular harvesting and water level drawdown, saltwater progress and some wells in the discharge area have been salty, so in term of agricultural irrigation is causing problems. Hoxhaj [12] could prove salt water intrusion into the aquifers of northern Albania based on observations of chloride concentration in five wells and geochemical studies. In addition, harmful effects on Irrigation are also emphasized.

\subsection{Study area of ghaemshar plain}

Study area locate from $52^{\circ}-35^{\prime}$ to $53^{\circ}-23^{\prime}$ of East longitude and from $35^{\circ}-44^{\prime}$ to $36^{\circ}-47^{\prime}$ of

North width in the Mazandaran province. Total latitude of study area is about $3348.1 \mathrm{Km}^{2}$, 
which the latitude of plain is $935.5 \mathrm{Km}^{2}$ and the rest of areas contain the northern highlands of Alborz (figure 1).

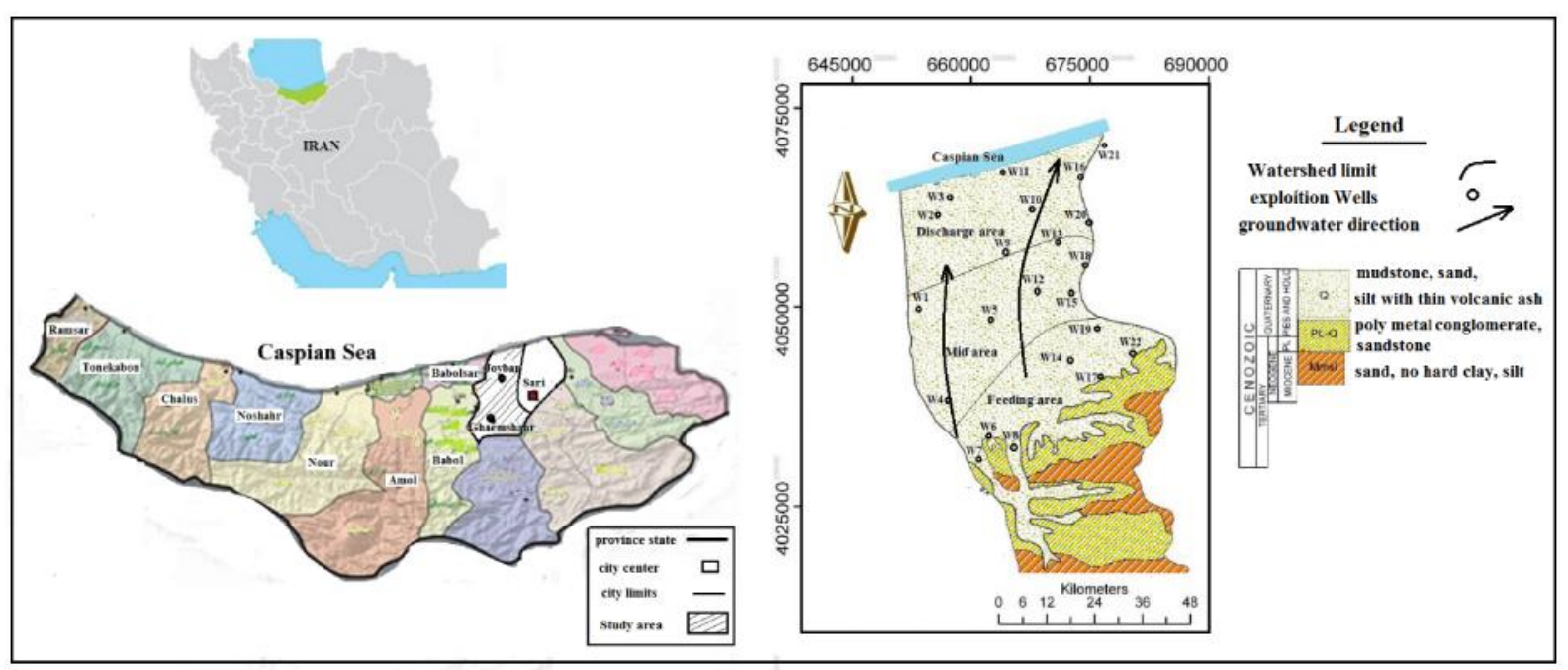

Fig.1. Geographical location, geological map and the location of sampling wells and groundwater direction of Ghaemshahr plain

\section{MATERIALS AND METHODS}

Analysis of water samples involves measuring density of main cations and anions and parameters such as: EC, T.D.S and pH. Institute of Standards and Industrial Research of Iran [13] was used for analyzing (table 1). Finally other parameters were calculated by chemical relations. The procedure of this research consists of: data collection, Ministry of Energy reports, Regional Water Authority, articles, theses and maps related to research and evaluation and the analysis of geochemical data of aquifers, drawing maps and charts using Excel and Surfer software. The interpretation of the results and the overall status of water in the aquifer are based on the relationship of water in the aquifer sediments and seawater constituents. Additionally agricultural qualities of the groundwater sources were assayed using Wilcox and some index such as permeability Index, sodium rate and etc. Since all components of water solution are as meq/L or $\mathrm{mg} / \mathrm{L}$, these units were used as required. In each analysis values of cations and anions should be equal. Errors in experiments and/or no measurement of elements or components of water can cause inequality of cations and anions. Ionic balance of assays were calculated by Reaction Error Relation, then Piper diagram, Wilcox and combinational diagrams were applied for surveying the aquifer type, mixture and the agricultural quality of 
the aquifer. Differences in value can result from experimental error or lack of elements and other substances in water, but should not be more then \%5 [14]. On this basis, the analysis error percentage of the Ghaemshahr Plain, in all cases, was less than the mentioned amount (table 2). Considering the ionic balance in the water samples, evaluation of water type and its mixture was done using the combination charts and diagram of Piper. Table 2 represents the data from hydrochemical analysis and reaction error (\%) is calculated from equation (1).

[( $\Sigma$ Cat. $-\Sigma$ Anion $) / \Sigma$ Ion $] \times 100=$ Reaction Error

Table 1. Measurement of elements and substances in groundwater [13]

\begin{tabular}{cccc}
\hline Elements and materials & Method & $\begin{array}{c}\text { Elements and } \\
\text { martial }\end{array}$ & Method \\
\hline $\mathrm{Mg}, \mathrm{Na}$ and $\mathrm{K}$ & Atomic absorption & $\mathrm{EC}, \mathrm{TDS}$ & Portable desert device \\
& spectrometry & $\mathrm{pH}$ & Portable desert device \\
$\mathrm{HCO} 3$ and $\mathrm{Cl}$ & Titration & $\mathrm{Ca}, \mathrm{TH}$, & Titration \\
$\mathrm{SO} 4$ & Spectrophotometer & alkalinity & \\
\hline
\end{tabular}

Table 2 Statistical specifications of the chemical analysis of selected resource in Ghaemshahr plain (ion values are $\mathrm{mg} / \mathrm{l}$ and $\mathrm{EC}$ is $\mathrm{S} / \mathrm{cm}$ for the mean of years from 1999 to 2014) (R.E.P;

Reaction Error Precentage) [15]

\begin{tabular}{|c|c|c|c|c|c|c|c|c|c|c|c|c|}
\hline 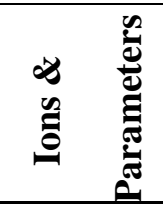 & $\bigcup_{\text {U工工 }}$ & $\tilde{\theta}$ & $\bar{I}$ & ש & $\sum^{+\infty 00}$ & $\stackrel{+\pi}{\mathbf{z}}$ & $\stackrel{+}{4}$ & $\stackrel{0}{0}$ & $\overline{0}$ & $\dot{0}$ & $\underline{\underline{E}}$ & 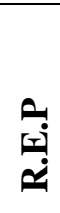 \\
\hline ISIRI[13] & 1000 & 500 & $6.5-8.5$ & 75 & 30 & 200 & 10 & 500 & 250 & 250 & 100 & \\
\hline
\end{tabular}

2014

\begin{tabular}{|c|c|c|c|c|c|c|c|c|c|c|c|c|}
\hline Mean & 1580.6 & 1015.6 & 7.3 & 123.3 & 50 & 118.1 & 3.6 & 487.1 & 190.8 & 101.7 & 949.8 & 0.78 \\
\hline Min & 627 & 407 & 6.7 & 64 & 14.4 & 13.8 & 2.7 & 231.8 & 21.3 & 14.4 & 502 & 0.1 \\
\hline Max & 6680 & 4275 & 8 & 338 & 180 & $876 . .3$ & 5.4 & 1024.8 & 1495 & 499.2 & 2374 & 3.5 \\
\hline
\end{tabular}

1999

\begin{tabular}{|c|c|c|c|c|c|c|c|c|c|c|c|c|}
\hline Mean & 1506.5 & 977.8 & 7.4 & 112.2 & 37.5 & 137.1 & 4.04 & 464.5 & 196 & 88.2 & 919.1 & 0.41 \\
\hline Min & 780 & 507 & 6.9 & 54 & 10.8 & 11.5 & 2.7 & 170.8 & 17.7 & 9.6 & 520 & 0.1 \\
\hline $\operatorname{Max}$ & 5330 & 2411 & 7.8 & 228 & $112 . .8$ & 1030.4 & 5.46 & 860.1 & 1472.2 & 768 & 1684 & 1.13 \\
\hline
\end{tabular}




\section{RESULTS AND DISCUSSION}

Borders of study area are limited to Caspian Sea in north and to Alborz Mountains at south. Ghaemshahr plain was formed such a bowl by the falling down of Caspian Sea, like the other alluvial aquifers. Fresh water deployed against the saltwater of sea and tried to stroke it back, but it didn't do complete, so that there are saltwater confines overall the alluvial. At the geological periods saltwater is carried by sediments slowly and forms the fossil saline (connate water) aquifers. Disturbance of equilibrium between the saltwater and fresh water and also quality of groundwater sources is inappropriate especially in the exits of the plain. Due to the excessive removal, the balance of fresh and saltwater is disturbed and quality of groundwater is markedly inappropriate especially in the outlet of the plain. Geological features of basin of Ghaemshahr which are most affecting factors contain lime, Marl, Dolomitic and sandstone sediments. It formed the deposits of alluvial fan in the lower elevations from south to north and also fine-grained sediments in the middle part to the beach (figure 1). In the surface of plains there is Caspian Formation (Quaternary) which is formed, from not-hard sandy clay. Abshoran Formation which has been formed, from not-hard clay, marl, sand is under these sediments with conglomerate of Upper Pliocene age-Quaternary. Alluvial fans and new Caspian Formation in hydrogeology have been defined as permeable and semi-permeable formations. Thickness of new aquifer in the plain of Ghaemshahr is changed from 25 meters to 70 meters. Water tables of groundwater are changed from 60 to -25 meters and they reduce from south to north. General order of water flow is from south to north and northeast in this plain (figure 1). There are 2752 deep wells in the study area to exploit its discharge 101.7 MCM per year. As well as 29209 semi-deep wells with a total evacuation of $110.3 \mathrm{MCM}$ per year, and 770 sparings with discharge $123.8 \mathrm{MCM}$ and 3 aqueducts drained 1.16 MCM. Totally there are 337 MCM removals and 3.5 MCM have been reduced from reservoir volume per year. Due to irregular withdrawal of groundwater resources for different uses (such as drinking, agriculture and industry), long-term statistics showed annual reduction of reservoir volume averaged $10 \mathrm{~cm}$ which leads to the drop in the groundwater level [16]. Main ions and the calculations of ratios of these ions, will help to understand and conclusions about the chemical affecting of rocks on the composition and 
quality of groundwater. The effective factors in the geochemical controlling mechanisms of groundwater are hydro- climatic conditions, excessive withdrawal of water resources, geological formations, the reaction between the rock - water and ions relative variability. According to the analysis in the 1999 and 2014 years, the orders of groundwater ions are represented in the Table 2. By using mean of, in 1999 as frequency ion: $\mathrm{Na}+\mathrm{K}>\mathrm{Ca}>\mathrm{Mg}$, $\mathrm{HCO} 3>\mathrm{Cl}>\mathrm{SO} 4$, and in 2014 has been $\mathrm{Ca}>\mathrm{Mg}>\mathrm{Na}+\mathrm{K}, \mathrm{HCO} 3>\mathrm{Cl}>\mathrm{SO} 4$. Compositions and frequency of ions is influenced by sand, clay, marl, silt sediments (plains) and deposits of limestone, marl and dolomite (Height). Therefore, in order to understand the chemical features of natural state of groundwater, piper diagram[17] and determination of main anion and cation points on the diagram can be used to identify facies the study of area (figure 2).

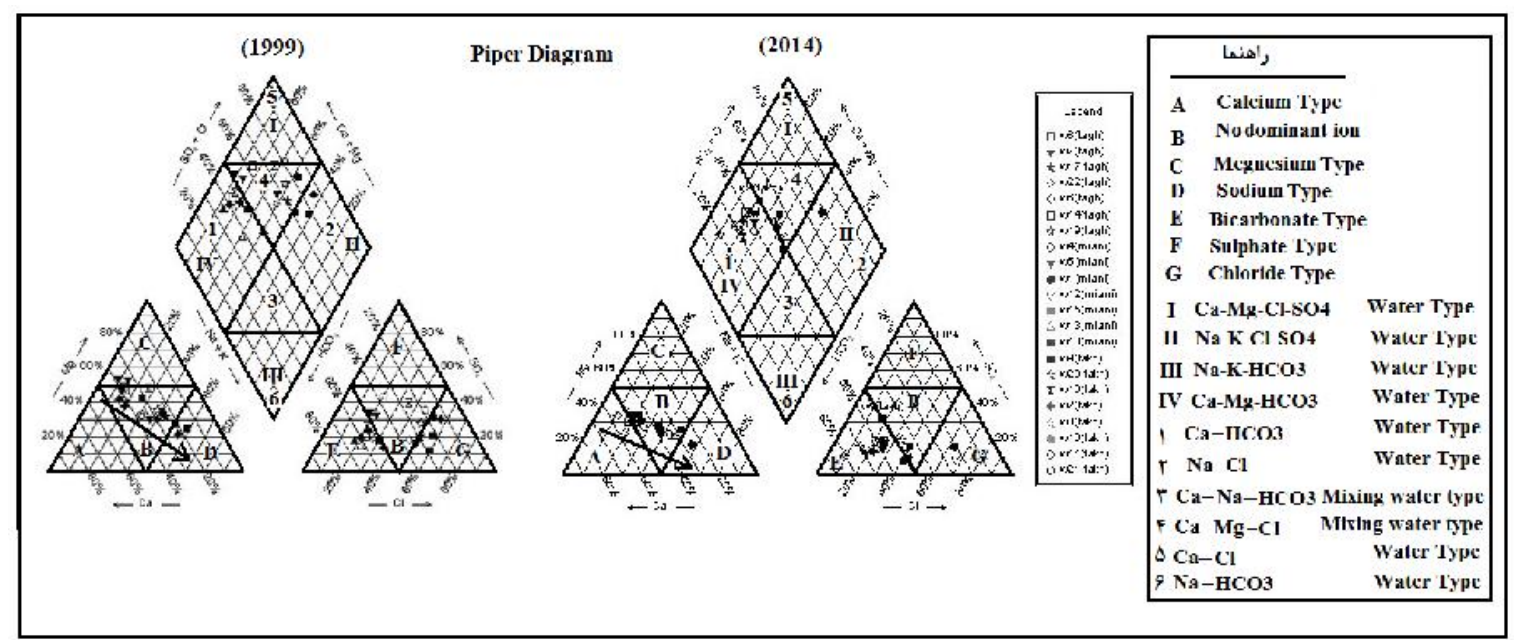

Fig.2. Piper diagram to classify geochemical and hydro - geochemical parameters

As it is represented in the figure, all samples are in the piper diamond diagram of the 4,1 and 2 areas (1999). These waters are type (Ca-Mg-Cl) (4), Calcium Bicarbonate (1) and sodium chloride (2) mixtures i.e. main type of mixtures of waters is calcium carbonate. While most samples for 2014 are in the range of one and four. Indeed, calcium carbonate and waters mixed with sodium chloride are the predominant types. Due to the calcareous, marl and dolomite deposits, weathering of them and reaction of water and rocks, it can be understood that large amounts of resolved calcium and magnesium are entered to aquifer from the highlands of study area. According to Tablel 3, water available in the study area from 1999 to 2014 a lot has changed in such a way that the mixing of waters from $22.7 \%$ to $27.27 \%$ water and bicarbonate of $45.5 \%$ to $\% 63.63$ increase has found. The most important issue is a decline 
from $27.2 \%$ to $9 \%$ saline solution is reached. These changes can result from withdrawals of control, increase infiltration, reduce evaporation and control pollution sources such as use of fertilizers in agriculture and wastewater, rural and industry.

Table 3. Classification of groundwater resources in the study area (mean of 1999 and 2014)

\begin{tabular}{|c|c|c|c|}
\hline Year & Wells & Water Type & $\%$ \\
\hline \multirow{2}{*}{1999} & $\mathrm{~W} 11, \mathrm{~W} 19, \mathrm{~W} 22, \mathrm{~W} 5, \mathrm{~W} 3$ & $\mathrm{Ca}-\mathrm{Mg}-\mathrm{Cl}$ & 22.7 \\
& $\mathrm{~W} 2, \mathrm{~W} 13, \mathrm{~W} 20, \mathrm{~W} 9, \mathrm{~W} 12, \mathrm{~W} 14, \mathrm{~W} 17, \mathrm{~W} 8, \mathrm{~W} 7, \mathrm{~W} 6$ & Ca-Mg-HCO3(Ca-HCO3) & 45.5 \\
& $\mathrm{~W} 21, \mathrm{~W} 16, \mathrm{~W} 10, \mathrm{~W} 18, \mathrm{~W} 15, \mathrm{~W} 1$ & $\mathrm{Na}-\mathrm{Cl}(\mathrm{Na}-\mathrm{K}-\mathrm{Cl}-\mathrm{SO} 4)$ & 27.2 \\
& $\mathrm{~W} 4$ & $\mathrm{Ca}-\mathrm{Mg}-\mathrm{Cl}-\mathrm{SO} 4(\mathrm{CaCl})$ & 4.5 \\
\hline \multirow{2}{*}{2014} & $\mathrm{~W} 11, \mathrm{~W} 10, \mathrm{~W} 20, \mathrm{~W} 18, \mathrm{~W} 13, \mathrm{~W} 9$ & $\mathrm{Ca}-\mathrm{Mg}-\mathrm{Cl}$ & 27.27 \\
& W21,W3,W2,W10,W5,W4,W14,W19,W22,W17,W8,W7,W6,W1 & Ca-Mg-HCO3(Ca-HCO3) & 63.63 \\
& $\mathrm{~W} 16, \mathrm{~W} 12$ & $\mathrm{Na}-\mathrm{Cl}$ & 9 \\
\hline
\end{tabular}

\section{- Agricultural quality of water}

In terms of agriculture production, high quality water is required. Suitability of irrigation water which is an evaluating about the determination of elements such as sodium, magnesium, chlorine and also the amount of sodium rate, risk of magnesium, residual sodium carbonate, sodium absorption rate, permeability rate and etc. the status of groundwater elements and parameter is represented in table 2 briefly and determination of water features in terms of agriculture is showed in table 3. Effective factors have been assessed below;

- Sodium and Chloride: in order to such elements such as calcium, magnesium, potassium, bicarbonate and sulfate there is no problem and the situation has improved from 1999 to 2014. In the plain of Ghaemshahr the source of sodium is weathering of clay minerals which contain the sodium and potassium with also saline water entering (fossil saline aquifers and salt water of Caspian Sea). Since, potassium is resistant to weathering, interacts lower, so that the amount of these elements in the groundwater is low. The chemical reactions, chloride don't inter into the absorption and ion exchange reactions. Chloride trends of changes in the plain follow the electrical conductivity (EC) and so TDS. Therefore, the combined diagram of chloride than $\mathrm{Na}^{+}, \mathrm{K}^{+}$and TDS was plotted and a linear tender was observed which is based on the saline water penetrations to the fresh water and also its correlation coefficient improved in 2014 than 1999 (figure 3). 


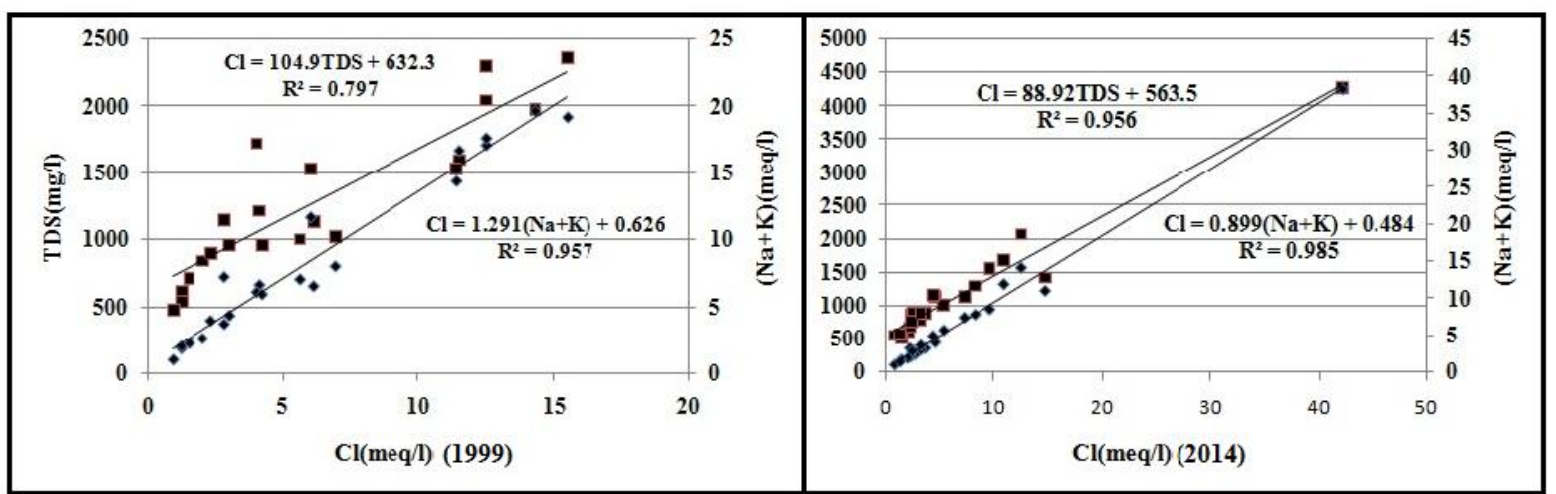

Fig.3. Comparisons the changes of $\mathrm{Cl}$ relative to TDS and sodium+ potsium in the study area

In the chloride with sodium + potassium diagram, correlation curve passes through the origin of coordinates which it means none of the ions are predominant to other ions. Due to the characteristics and chemical compositions of these two elements, that chloride is never affected by chemical processes such as adsorption and ion exchange and unlike sodium acts variable according to geological conditions, level of weathering, amounts of entering halide fluids into the environment and other active factors.

- Total dissolved Solid (TDS) and Electrical Conductivity (EC): The relation of EC and TDS was plotted by the combinational diagrams and they were compared together (Fig. 4). According to the figure, there is a clearly linear relation between the EC and TDS in and its coefficient is about 0.64 from 1999 to 2014. Values of EC and TDS are very important in irrigation and the classification of them is very considerable in terms of consumption (Table 1). According to the diagram of figure 5, the amounts of EC and TDS which are more than $2250 \mathrm{~S} / \mathrm{cm}$ and $3000 \mathrm{mg} / \mathrm{l}$ can be based on the saline water penetration (sea and fossil saline aquifer).

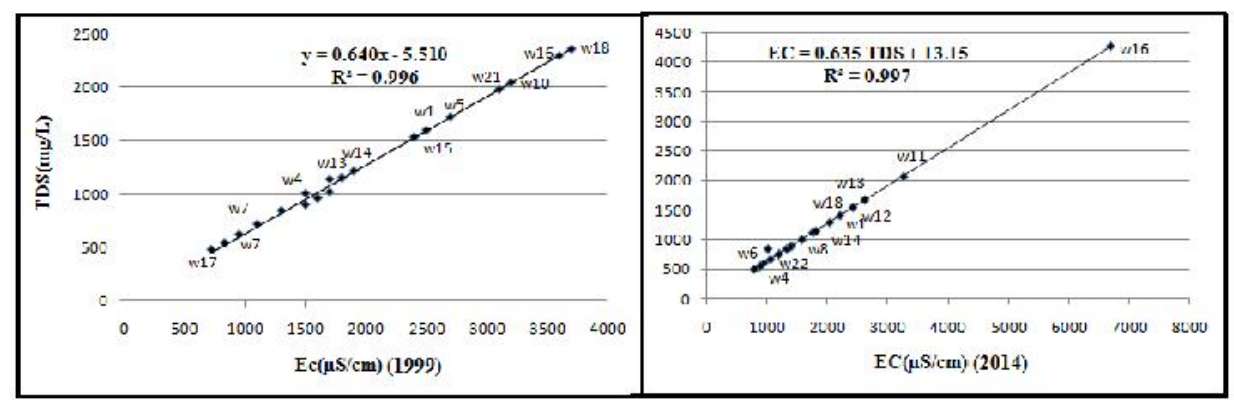

Fig.4. Comparisons the changes of EC relative to TDS in the study area 
- Sodium Absorption Rate (SAR): changes of the EC values and the rate of sodium absorption are the most important factors for irrigation. Irrigation waters are classified in different groups according to the risk level of saline (C), risk of sodium (S) (Alkali) and Sodium Absorption Rate (SAR). High concentration of sodium in the soil reduces the permeability and thus extends the alkaline soil. Indeed, waters with high concentration of sodium and low concentration of calcium saturate with sodium by ion exchange that leads to disintegration of clay minerals and reduction of plant growth [18]. High cumulative concentration values of $\mathrm{HCO} 3+\mathrm{CO} 3$ than $\mathrm{Ca}+\mathrm{Mg}$ ions, shows interaction of residual carbonate with sodium and it means the risk of sodium. SAR can be calculated by the equation (2):

$\operatorname{SAR}=\mathrm{Na} / \sqrt{\mathrm{Ca}+\mathrm{Mg}) / 2}$

According to the EC or risk of saline, rate of allowed waters were increased and the rate of unsuitable waters were decreased from 1999 to 2014. Therefore conditions are improved in 15 years. Water resources were classified of irrigation by Wilcox diagram [19] that is shown in the figure 5. Wilcox diagram represents is suitable for irrigation in most groundwater resources. Samples of 1999 are in the C3S1 areas (13 samples), C2S1 (one sample, fresh, harmless), C4S1 (8 samples) and samples of 2014 are in the areas as C3S1 (17 samples), C3S2 (one sample) C4S1, C4S2, C4S4 (1, 2 and 1 samples) (table 4). Using Table 4 and Figure 5, water quality of agricultural zoning map is drawn (figure6). Figure 6 shows, in the past 15 years (1999-2014) of quality water resources for agriculture in the direction of groundwater flow has improved and unsuitable areas have moved towards the discharge.

Table 4. Classification of agricultural water in Ghaemshar plain [18]

\begin{tabular}{|c|c|c|c|c|c|c|c|}
\hline class & $\%(1999)$ & $\%(2014)$ & SAR & $\%(2014)$ & $\%(1999)$ & class & EC \\
\hline S1(excellent) & 100 & 95.5 & SAR $<10$ & --- & --- & C1(excellent) & EC $<250$ \\
\hline S2(good) & --- & 4.5 & $10<$ SAR $<18$ & --- & 4.5 & C2(good) & $250<$ EC $<750$ \\
\hline S3(doubtful) & --- & --- & $18<$ SAR $<26$ & 81.8 & 59.1 & C3(permissible) & $750<\mathrm{EC}<2250$ \\
\hline S4(unsuitable) & --- & --- & SAR $>26$ & 13.6 & 36.4 & C4(unsuitable) & $2250<$ EC $<5000$ \\
\hline S5(very high) & --- & --- & -- & 4.6 & --- & $\begin{array}{c}\text { C5(unsuitable) } \\
\text { (very high) }\end{array}$ & $>5000$ \\
\hline
\end{tabular}



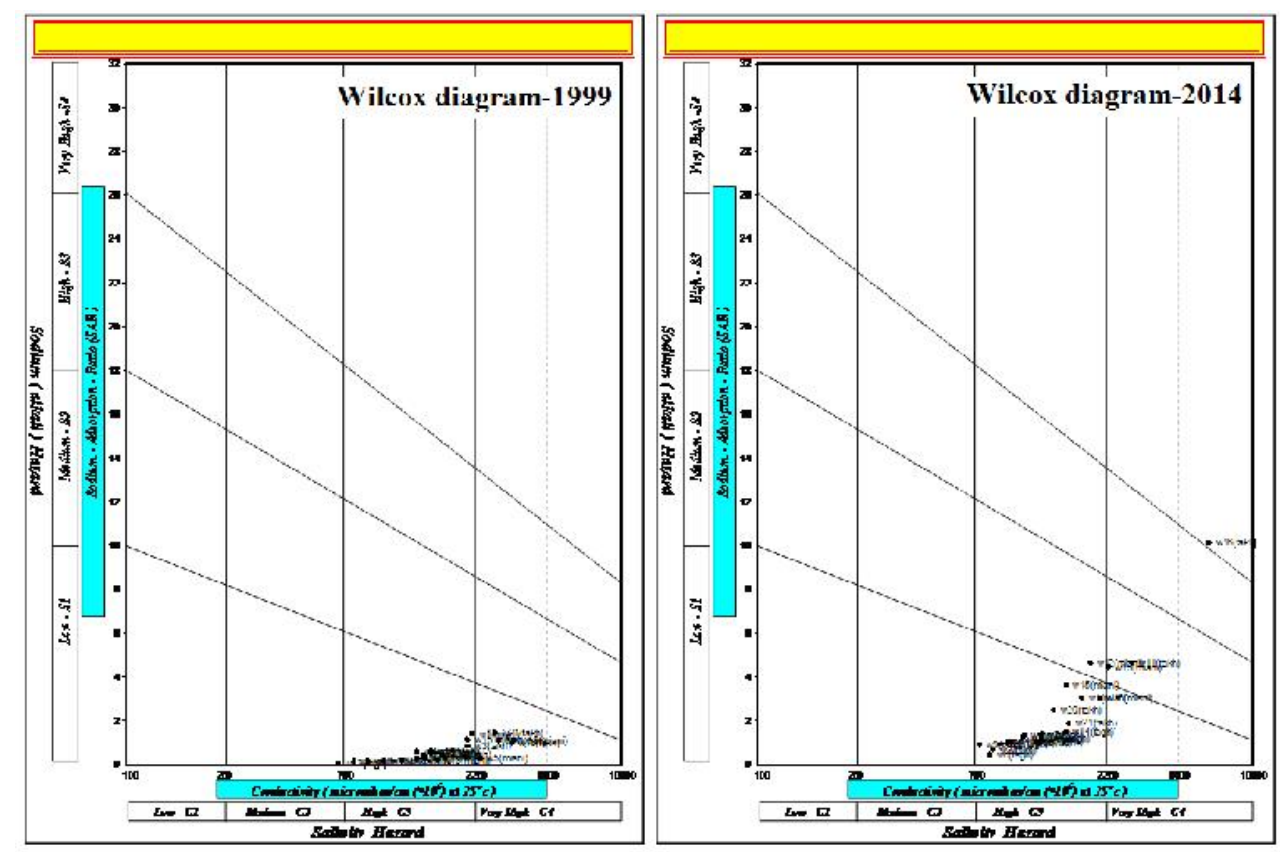

Fig.5. Diagram of Wilcox for study area

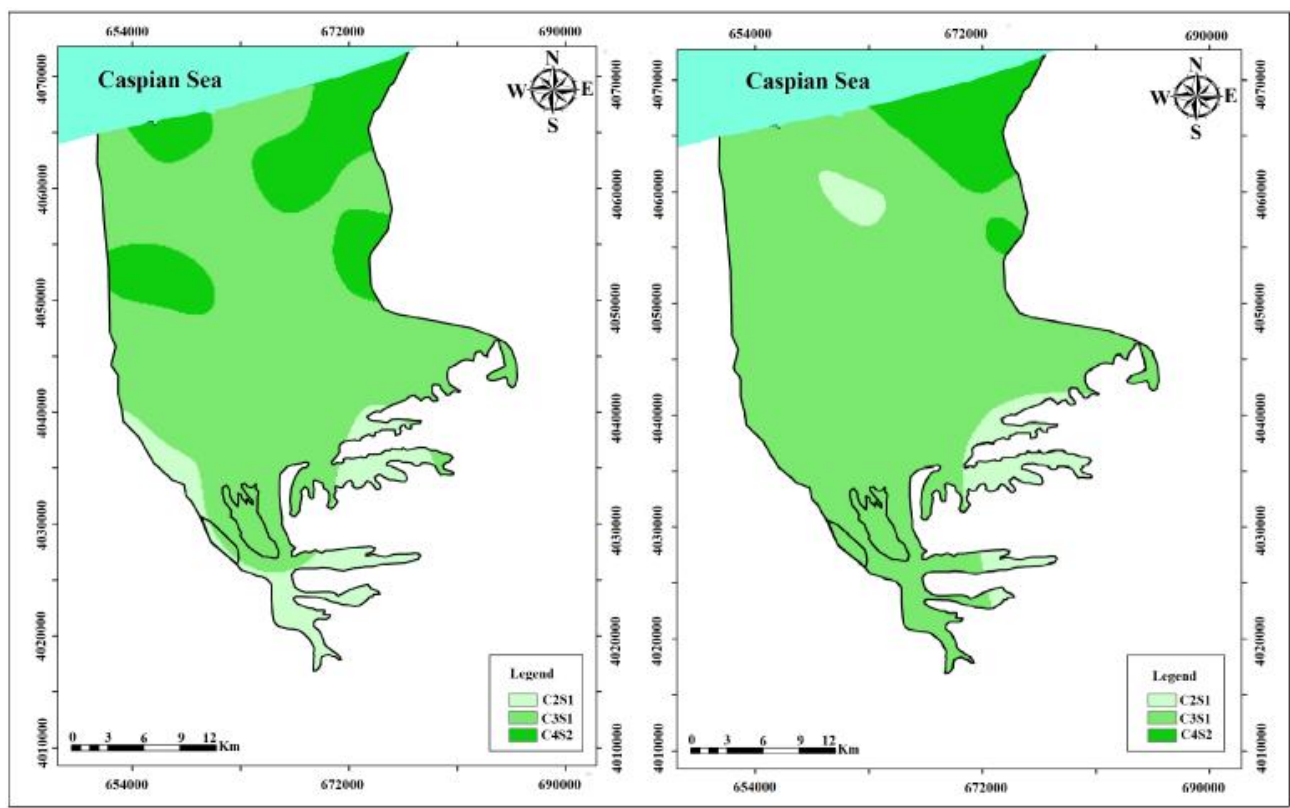

Fig.6. Ghaemshar plain zoning map of agriculture for 1999(left) and 2014(right)

Since the feeding is from heights, penetrated water into the fresh aquifer causes the mixture in the middle part and then it reduces the concentration of saline water which comes from fossil saline aquifer and conducts this water to the discharge area.

- Sodium Rate: Sodium rate represents the sodium amount of irrigation [19]. Clay grains absorb the sodium when this ion increases in irrigation, so that calcium and magnesium ions 
are diffused. Exchange of sodium ion from water with calcium and magnesium from soil, decreases the permeability of soil. Sodium rate is calculated by equation (3) (units: meq/l):

$$
\% \mathrm{Na}=\left(\mathrm{Na}^{+1}+\mathrm{K}^{+1}\right) * 100 /\left(\mathrm{Ca}^{+2}+\mathrm{Mg}^{+2}+\mathrm{Na}^{+1}+\mathrm{K}^{+1}\right)
$$

Regarding to equation (3), in 1999 most of samples were in the Good (41\%), Allowed $(31.8 \%)$ and doubtful (13.6\%), whereas in 1390, samples were in the Very good $(22.7 \%)$, Good (54.5\%) and allowed (22.8\%), in the study area. Statuses of the samples have been improved in 1390 and there is no problem with irrigation. In the feeding area, the area of "very good" has extended considerably because the feeding amount has increased from southern height of plain. Fossil saline aquifer in the groundwater direction flow (from middle part to the east) and penetration of Caspian Sea water caused to mix the fresh and saline water and also increasing the saline of water in the discharging area.

- Permeability Index (PI): long-term using of irrigation water affects the permeability of soil and components of the soil such as calcium, sodium, magnesium and bicarbonate. Doneen [20] introduced a standard in determining the usability of water for irrigation and called that Penetrating Index. This index is calculated by equation (4) (All units are meq/l):

$\mathrm{PI}=\left[\left(\mathrm{Na}^{+1}+\sqrt{\mathrm{HCO}}-\right) /\left(\mathrm{Ca}^{+2}+\mathrm{Mg}^{+2}+\mathrm{Na}^{+1}+\mathrm{K}^{+1}\right)\right] \times 100$

According to the Doneen's explanation, PI is classified into three categories, which the first class contains more than $75 \%$ permeability and is good water, and the second class is suitable type of water. Third class which has maximum $25 \%$ permeability contains the unsuitable water. Amounts of this index for 1999 and 2014 are in the first and second class, so that they contain good and suitable waters. In the past 15 years (In terms of irrigation water standard, is not potable), saltwater couldn't penetrate and advance into the fresh aquifer and didn't diffuse into them, because feeding of the height were increased and groundwater flow of fresh water was strengthened. As a result; all of areas were in the 1 and 2 categories.

- Residual Sodium Carbonate (RSC) and Magnesium Hazard (MH): Desired conditions of sedimentation (calcium and magnesium) are provided when concentrations of bicarbonate and carbonate are more than calcium and magnesium concentration. RSC amount represents these effects and residual sodium carbonate factor is used to recognize the property of irrigation water [21]. RSC is calculated by the equation (5) (all units are meq/l): 


$$
\mathrm{RSC}=\left(\mathrm{CO}^{-2}+\mathrm{HCO}^{-}\right)-\left(\mathrm{Ca}^{+2}+\mathrm{Mg}^{+2}\right)
$$

Unsuitable water for irrigation is determined by more than 2.5 amount of RSC. $1.25-2.5$ amounts of RSC show the relatively qualified water and the lower than 1.25 and negative amounts of RSC explain the suitable and excellent water for irrigation. RSC values of the study area in 1999 were $91 \%$ in the suitable and excellent levels (86.3\% and $4.7 \%$ ) also in 2014 these values were $100 \%$ that explain the suitable and excellent (100\% negative amounts) water for irrigation. RSC values which were positive (0-1.25) explain the solving of calcium and magnesium compounds when they were more than bicarbonates. Additionally the first and second classes were destroyed and all waters advanced to the suitable and excellent classes of quality. Usually calcium and magnesium play the roles of balancer in water [5]. Since chemical equilibrium affects the firm areas negatively, for determination of magnesium effect in the irrigation water the Magnesium Hazard used. Pally Wall [22] presented an index for calculation the magnesium rate. Higher than $50 \%$ is inappropriate and lower of them are suitable to irrigate. This rate is calculated by equation (6) (ions meq/l):

$$
\mathrm{MH}=\left[\mathrm{Mg}^{+2} /\left(\mathrm{Ca}^{+2}+\mathrm{Mg}^{+2}\right)\right] \times 100
$$

According to the calculations in $1999,90.9 \%$ of samples are in suitable levels and the rest are unsuitable in the study area. In 2014 all of samples are in the suitable level.

- Kelly Index (KI): Kelly method is one of the more useful methods for classification of irrigation water. Kelly [23] introduced the KI by measuring all of sodium concentrations and dividing them to the sum of magnesium and calcium concentrations. In this index, lower than 1 are classified as suitable and more than 1 are unsuitable. KI for samples of 1999 are lower than 1 and suitable and $27.2 \%$ of them are unsuitable. In 2014 the suitable levels increase to $95.5 \%$ and unsuitable levels decrease to $4.5 \%$.

- Soluble Sodium Percent (SSP): considering that sodium is important to use in all sources of water, percent of this element is used for surveying the quality of irrigation water [19]. High amounts of sodium in the irrigation waters cause exchange of water sodium with calcium and magnesium of soil. These reactions, reducing permeability and consequently weakens the soil drainage (equation 7). For this reason the concept of the equation $12 \%$ sodium solution is obtained, used (units are meq/l): 
$\mathrm{SSP}=\left[\left(\mathrm{Na}^{+}+\mathrm{K}^{+}\right) \times 100\right] /\left(\mathrm{Ca}^{+2}+\mathrm{Mg}^{+2}+\mathrm{Na}^{+}+\mathrm{K}^{+}\right)$

Due to the Wilcox relation and the classification of $1999,54.5 \%$ are in the good level, $31.8 \%$ are in allowed level and $9.1 \%$ are in doubtful. Whereas, in 2014, 77.2\% are in good level, 22.7 are in the allowed level. Most of the groundwater samples in the study area are in the good and allowed levels and there is no problem to use them.

\section{CONCLUSION}

According to the values and classification of factors such as EC, Na\%, SAR and TDS and other factors, in this study, the status of groundwater resources the water used in irrigation Ghaemshahr plain provided as follows:

Irrigation water of most groundwater sources from feeding to discharging area based on the plains and zoning are suitable. The high water table and an increase in evaporation, a substantial amount of salt precipitated on the next rainfall dissolves and are added to the aquifer. Additionally, excessive and drop in the groundwater level lead to attack the seawater to the freshwater and mix with it. Some of the calcium and sodium ions which are the lime, marl and dolomite sediments of highlands solution results, exchange in the groundwater direction and affected by the fossil saline aquifers which are in the east of middle part. The exchanges can injection to the fresh aquifer by spraying or by exchange and reverse exchange reactions in the study area. In this study the effects of contaminates weren't studied and it is need to study the effects of contaminates in the water sources (surface and groundwater) seriously and rapidly. Entering the sewerage of agriculture urban and industrial activations along the rapid population growth, increase in cultivated land, and irrigation manner cause reduces the aquifer quality more rapidly. Since groundwater provides the consumption of water in Ghaemshahr plain, it is need to manage about making integrating agricultural land, determination the type of the cultivation, irrigation approaches and controlling the removal of groundwater. Because by this manner, and due to increasing the EC, TDS, SAR and Na\%, saline area will extend rapidly and all of the area will be saline at future years. Therefore groundwater quality will decrease for using in agriculture and the other consumptions and also infiltration of them will not be useful because optimum using and controlling the water 
resources (surface and groundwater) are the priority of countries. If a country fails to control resources and have at hand faced with water scarcity will seriously of drought that resulted in a sharp decline in water re and food resources. But the increase is necessary Regional Water Organization of indiscriminate harvesting on its agenda Put and manage the use of water resources to improve irrigation efficiency into consideration.

\section{REFERENCES}

[1] Guler, C., Thyne, G. McCray, J. Evaluation of graphical and multivariate statistical method for classification of water chemistry data, Hydrogeology Journal., 2002, 10, 455- 474.

[2] World Health Organization (WHO). Guide lines for drinking water 2nd Edition vol. 2 Health criteria and other information genera Switzerland, 2004, 281-308.

[3] Subramani,T., Elango, L. and Damodarasamy, R. Groundwater quality and its suitability for drinking and agriculture use in Chithar River Basin, Tamil Nadu, India, Environmental Geology, 2005, 47, 1099-1110.

[4] Guler, C., Thyne, G. Hydrologic and geologic factors controlling surface and groundwater chemistry in Indian Wells- Owens Valley area, SE California, USA, Journal of Hydrology, 2004, 285, 177-198.

[5] Hem, J.D., Study and interpretation of the chemical characteristics of natural waters, 3th edn. USGS water supply paper 2254, 1985, 117-120.

[6] Water sources researches organization, (Tamab), the project of embargo extension about drinking water providing area of Ghaemshahr-Babol-Kiaklar- Bahmanir- Joybar, Iran, 1997.

[7] Alexander Gibb engineers company, Study of Talar-Babol- Haraz River areas, 1975.

[8] Mahabghods Consulting Engineers, accurate semi-formal Agrology studies of Talar-Babol-Haraz River, Iran, 1991.

[9] Mostafavi, R., Hydro geochemical analysis and modeling of groundwater flow of drinking water wells in the city of Sari, Hydrogeology master's thesis, Tarbiat Moallem University of Tehran, Faculty of Earth Sciences, Department of Geology, 2009.

[10]Kaboli, A., Quality and quantity surveying the sari plain basin, Master theses of groundwater, department of geology, Shahid Beheshti University, 2003. 
[11] Gharemohammadlu, M., Raghimi, M., Tahmasebi, A., Using hydrochemistry ti detect the saline water penetration into the water wells (Case study of urbanism), Agricultural Sciences and Natural Sources Journal, 2007, 15 (4).

[12]Hoxhaj, F, Numerical Simulation of sea Water intrusion on northern coast of Albania, Geophysical Research Abstracts, 2005, 7.

[13] Institute of Standards and Industrial Research of Iran, physico-chemical characteristics of water (Standard Number: 1053), 1388, Fifth Edition, 1-18.

[14]Hounslow, A.W., Water quality data analysis and interpretation, Lewis publishers, CKC Press, LLC. 1995, 392.

[15]Mazandaran regional water authority, Statistic measuring the water level in observation wells, chemical analysis and other information, 2014.

[16]Moghimi, H. Hydrogeochemical assessment of Ghaemshar- Joybar aquifer plain (North East of Iran): Research Project Report; No: 94/15/23/4081, Payam-e Noor University (Abhar -Zanjan Branch), 2015.

[17]Piper, A. M., A graphical procedure in the geochemical interpretation of water analysis, Transactions- American geophysical Union, 1944, 25, 914-928.

[18]Todd, D.K., and Mays L.W., Groundwater Hydrology, John Wiley\& Sons, New York, $2005,535$.

[19]Wilcox, L. V., 1955, Classification and use of irrigation waters, USDA, circular 969, Washington DC, USA.

[20]Doneen, L. D., Water quality for Agriculture, Department of Irrigation, University of California, Davis, 1964, 48.

[21]Richards, L. A. Diagnosis and improvement of saline and alkali soils, US Department of Agriculture, Hand Book 60, 1954, 160.

[22]Paliwal K.V., Irrigation with saline water [z], Monogram No. 2(new series). IARI, New Delhi, 1972, 198.

[23]Kelly, W.P. Permissible composition and concentration of irrigated waters, In: Proceedings of the ASCF66, 1940, 607. 
How to cite this article:

Moghimi H. Hydro - chemical study of agricultural water in the Ghaemshar plain (northeast of Iran). Appl. Sci., 2016, 8(2S), 284-300. 